\title{
Aspectos Clínicos Da lctiose Vulgar: Relato De Caso Clínico
}

\author{
Cunha, C.E.; Jornada, F.M.; \\ Apresentador: Carlos Eduardo Cunha
}

\section{Resumo}

Introdução: É uma patologia associada com um acúmulo excessivo de queratina que resulta num aspecto de pele semelhante a escamas (ictios - peixe). Há um acúmulo do stratum corneum com pouca ou nenhuma inflamação. Ela pode ser herdada geneticamente de forma autossômica dominante ou adquirida. As duas formas se assemelham porém, a forma adquirida é acompanhada de fatores sistêmicos. A mutação ocorre no gene FLG, que codifica a proteína epidérmica filagrina, responsável pela agregação de filamentos intermediários de queratina. Clinicamente há escamas finas que predominam nas áreas extensoras dos membros inferiores. Há associação com atopia bem como com ceratose pilar. Raramente ocorre hiperidrose, e o quadro clínico tende a melhorar no verão. A histopatologia é de hiperceratose com hipogranulose ou agranulose. Relato de caso: Paciente de 53 anos, feminina, procura UBS devido diagnóstico de ictiose vulgar há mais de 45 anos, apresentando no momento piora da descamação da pele associada a prurido em braços e costas que não a deixavam dormir à noite. Relata que possui um filho com 11 anos e o mesmo também apresenta a doença, porém com descamação menos intensa, sendo menos sintomático que a mãe. A paciente descobriu a doença na infância devido descamação e ressecamento na pele, o que fez procurar médico que diagnosticou ictiose vulgar.Nos meses de inverno a mesma relata piora dos sintomas, sendo que há uma semana começou com quadro de descamação e piora do ressecamento.Foi avaliada na UBS e receitado creme de uréia a $10 \%$ para hidratação da pele.

Discussão e revisão de literatura: A apresentação mais comum é um indivíduo com aspecto característico, prurido, pele seca e possivelmente fissura e infecções secundárias. A prevalência de Ictiose Vulgar hereditária (IVH) varia mundialmente em um estudo em Berkshire, Inglaterra se observou uma freqüência 1 caso em 250 crianças em idade escolar. Ictiose vulgar adquirida é extremamente rara e sua prevalência mundial é desconhecida. IHV não tem predisposição de etnia ou sexo. Normalmente a IVH está ausente ao nascimento, mas se manifesta a partir do primeiro ano de vida e a maioria dos indivíduos já tem sintomas clínicos com 5 anos de idade. Já a forma adquirida se manifesta durante a vida adulta. As formas leves, como as ictioses comuns (vulgar e ligada ao cromossomo X), geralmente podem ser controladas com cuidados tópicos, enquanto casos graves necessitam de terapia sistêmica.

\section{Referência:}

Cunha, C.E.; Jornada, F.M.;. Aspectos Clínicos Da Ictiose Vulgar: Relato De Caso Clínico. In: II Congresso Brasileiro de Medicina Hospitalar - II CBMH [= Blucher Medical Proceedings, vol.1, num.5] São Paulo: Editora Blucher, 2014. p.31 DOI 10.5151/medpro-II-cbmh-024 